\title{
Penerapan Healing Environment pada Interior Instalasi Kebidanan dan Kandungan
}

\author{
Astrini Hadina Hasya dan Nanik Rachmaniyah \\ Departemen Arsitektur, Fakultas Teknik Sipil dan Perencanaan, Institut Teknologi Sepuluh Nopember (ITS) \\ e-mail:nanik@interior.its.ac.id
}

\begin{abstract}
Abstrak-Ibu hamil dan melahirkan memiliki tingkat kestabilan emosi dan perilaku yang berbeda dari ibu-ibu lainnya yang tidak dalam masa tersebut. Tren yang terjadi pada ibu hamil atau melahirkan saat ini adalah mempersiapkan matang penyambutan buah hati mereka, dimana rumah sakit khusus bagian kebidanan dan kandungan (obgyn) merupakan alternatif utama sarana mempersiapkan kelahiran mulai dari pemeriksaan kandungan, senam hamil, hingga pilihan melahirkan dengan berbagai metode. Menariknya, tren ini berfokus pada kenyamanan bayi saja, sehingga perhatian terhadap ibu itu sendiri secara fisik dan mental seringkali terabaikan. RS Kartika Husada Jatiasih sebagai rumah sakit umum dengan pelayanan unggulan utama pada kebidanan dan kandungan memiliki misi pelayanan prima bagi pasien. Untuk menunjang misi tersebut, maka diperlukan pengaplikasian desain interior yang sesuai karakter ibu hamil dan melahirkan utamanya melalui lingkungan positif penyembuhan (healing environment) yang akan berpengaruh pada kenyamanan fisik dan mental ibu hamil dan melahirkan. Hal ini dapat dilakukan dengan mendesain tata layout ruang beserta furnitur yang efisien dan menunjang aktivitas pengguna, serta memberikan desain interior yang menciptakan suasana nyaman, damai, tidak terkesan kaku dan dingin namun tetap menjunjung kehigienisan. Desain Interior yang tepat, dapat menyelasaikan permasalahan RS Kartika Husada Jatiasih. Visualisasi konsep desain yang diterapkan tersebut adalah penggunaan bunga lavender sebagai lambang healing yang feminin sebagai penggambaran yang cocok bagi ibu hamil dan melahirkan ditinjau dari manfaat dan filosofi warna yang terkandung menurut para ahli. Selain itu, kombinasi warna alam seperti hijau, krem, dan warna kayu menambah nuansa healing. Bentukan furnitur, pengaplikasian treatment pada dinding, pola lantai, plafon, serta pencahayaan maksimal alami dari matahari dan pencahayaan buatan berupa warm lighting mengarahkan ibu hamil dan melahirkan khusunya untuk lebih rileks dan nyaman pra dan pasca persalinan.
\end{abstract}

Kata Kunci-Ibu hamil dan melahirkan, healing environment, Interior Instalasi Kebidanan dan Kandungan.

\section{PENDAHULUAN}

$\mathrm{H}$ EALING ENVIRONMENT berasal dari Bahasa AngloSaxon Haelen yang berarti keseluruhan atau dapat pula diartikan sebagai keselarasan antara pikiran, tubuh, dan jiwa. Pada konteks makna, healing environment berarti lingkungan penyembuhan. Lingkungan penyembuhan yang positif penting dan sangat diperlukan utamanya pada interior bangunan yang menunjang fasilitas kesehatan. Oleh karena itu, faktor-faktor healing environment perlu diperhatikan demi mewujudkan lingkungan positif bagi pengguna agar mempercepat proses penyembuhan, diantaranya adalah hubungan dengan alam, memberikan pasien rasa kontrol untuk mengurangi stress secara signifikan, menyediakan akses dukungan positif utamanya dari keluarga dan kerabat, serta mencegah lingkungan negative seperti kebisingan dan kualitas buruk udara.

Ibu hamil dan melahirkan memiliki condong perubahan perilaku khusus yang dipengaruhi oleh perubahan hormonal. Perubahan-perubahan yang terjadi diantaranya adalah menjadi berkurang aktivitasnya, lebih sensitif, dan menjadi semakin cemas menjelang persalinan. Di Indonesia terdapat 37.300.000 orang ibu hamil, yaitu mengalami kecemasaan dalam menghadapi persalinan ada sebanyak 10.700 .000 orang $(28,7 \%)$. Di pulau jawa terdapat 679.765 ibu hamil, dengan 355.873 orang $(52,3 \%)$ mengalami kecemasaan dalam menghadapi persalinan (Depkes RI, 2008).

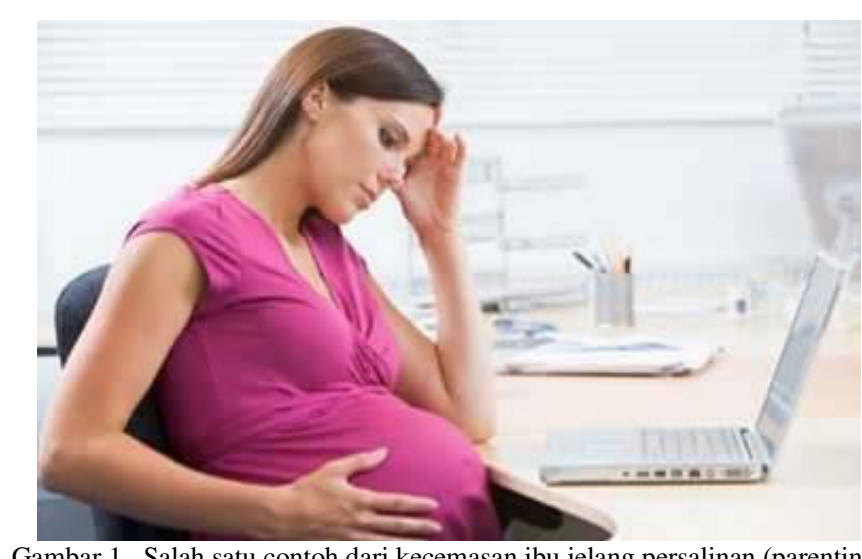

Gambar 1. Salah satu contoh dari kecemasan ibu jelang persalinan (parentingjournals.com)

Instalasi kebidanan dan kandungan dalam rumah sakit sebagai salah satu sarana pelayanan kesehatan ibu pra dan pasca melahirkan hadir untuk masyarakat yang memperhatikan secara khusus permasalahan para ibu. Upaya pelayanan maksimal diberikan dengan tujuan menciptakan kenyamanan khusus bagi para ibu dan mengurangi stress berlebihan, serta mempersiapkan matang fisik dan mental menyambut buah hati sesuai standar Departemen Kesehatan Republik Indonesia.

Berdasarkan latar belakang yang telah dijelaskan, untuk mengurangi kecenderungan stress pada ibu pra dan pasca melahirkan serta memberikan dukungan positif berupa kenyamanan dan ketentraman, maka diperlukan suatu desain interior yang menarik dan dapat memberikan citra baru sesuai visi misi rumah sakit, coorporate identity, segmentasi rumah sakit, dan keadaan lingkungan rumah sakit. Konsep yang akan dipakai pada desain interior Instalasi Kebidanan dan Kandungan RS Kartika Husada Jatiasih ini adalah rumah sakit sebagai sarana dukungan positif pasien dengan penerapan healing environment. 


\section{A. Rumusan Masalah}

1. Aktivitas pengguna kurang maksimal akibat kedekatan antar ruang tidak optimal

2. Instalasi kebidanan dan kandungan sebagai pelayanan unggulan utama kurang terlihat

3. Stress yang timbul pada ibu hamil dan melahirkan akibat kecemasan psikis

\section{B. Tujuan}

1. Menghasilkan rancangan interior yang efisien untuk menunjang aktivitas pengguna Instalasi kebidanan dan kandungan sebagai pelayanan unggulan utama kurang terlihat

2. Menghasilkan rancangan interior yang mendukung visi dan misi RS Kartika Husada Jatiasih

3. Menghasilkan rancangan interior yang merangsang psikologi positif pasien dengan penerapan healing environment

\section{Manfaat}

1. Secara akademis, diharapkan hasil pengerjaan perancangan ini dapat membantu menunjang proses belajar dan turut memajukan khazanah pendidikan di Indonesia.

2. Memberikan konsep instalasi kebidanan dan kandungan rumah sakit rumah yang baru dan menunjang kemajuan dari sektor kesehatan di Indonesia.

3. Sebagai bahan kajian lebih lanjut mengenai desain interior instalasi kebidanan dan kandungan RS Kartika Husada Jatiasih.

\section{URAIAN PENELITIAN}

\section{A. Metode Pengumpulan Data}

Menggunakan metode observasi yang bertujuan mengetahui kondisi riil dan terkini mengenai eksisting objek desain, khususnya pada interiornya dan area disekitar objek desain dan aktivitas pengguna, serta didukung oleh metode wawancara kepada pihak yang bersangkutan yakni salah seorang pengunjung dan pegawai rumah sakit mengenai keadaan rumah sakit. Metode kuisioner pada para ibu juga dilakukan, untuk menunjang data suasana seperti apa yang mayoritas diharapkan para ibu pra dan pasca melahirkan saat di rumah sakit.

\section{B. Metode Analisa Data}

Tahapan ini menganalisa data yang diperoleh di lapangan, berhubungan dengan kajian teoritis, dan kemudian dianalisa kembali, dari hasil analisa ini kemudian menghasilkan alternatif-alternatif desain, yang selanjutnya disimpulkan menjadi desain akhir.

\section{Metode Desain}

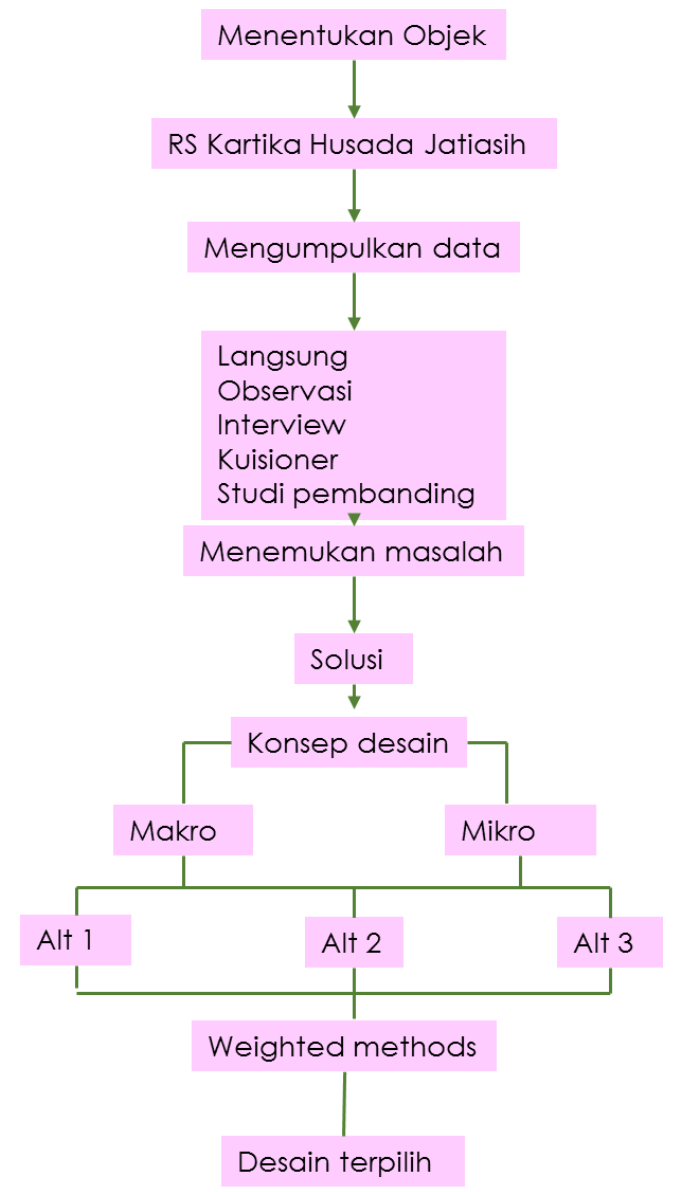

Gambar 2. Alur Metode Desain.

\section{KONSEP DESAIN}

\section{A. Konsep Makro}

Konsep utama yang digunakan adalah healing environment, yaitu konsep yang merangsang psikologi positif pasien dengan lingkungan penyembuhan yang memotivasi. Implementasi konsep pada desain melalui:

1. Pengelompokan layout ruang yang berkaitan fungsinya untuk memudahkan akses pengguna utamanya ibu hamil dan melahirkan berkaitan keterbatasan aktivitasnya.

2. Penggunaan bunga lavender sebagai lambang utama healing yang feminin dan cocok bagi ibu hamil dan melahirkan khususnya berdasarkan makna warna, karakteristik bentu, dan manfaat bunga menurut para ahli.

3. Penerapan bentuk furnitur, pola lantai, dan plafon lengkung yang dinamis dengan tujuan menggambarkan citra rumah sakit yang tidak kaku. 


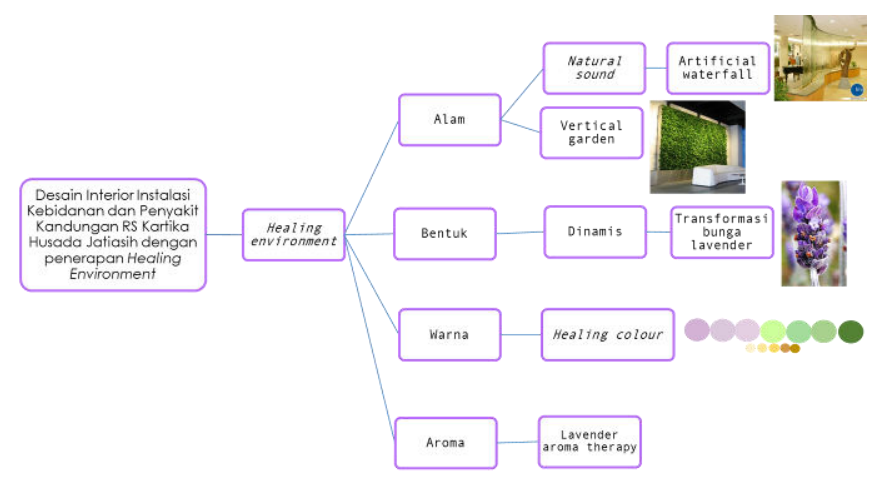

Gambar 3. Rancangan Konsep Desain

\section{B. Konsep Mikro}

\section{1) Konsep Warna}

Menurut Charless Philips dalam bukunya, Transform Your Life with Colours, 2015 warna ungu lavender merupakan warna mahkota chakra yang dipercaya mewakili spiritual, meditasi, relaksasi yang membangkitkan semangat. Sedangkan Menurut Terrence Conran dalam Conran on Color 2015 warna hijau merupakan warna paling menyejukkan, tentram dan tenang. Cocok dikombinasikan dengan warna-warna alam seperti cokelat.

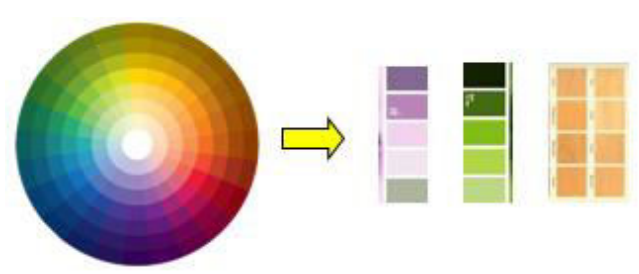

Gambar 4. Pemilihan warna berdasarkan colour therapy wheels

Penggunaan warna dalam desain ruang-ruang terpilih memiliki dominansi yang berbeda. Pada area medis namun membutuhkan privasi seperti kamar rawat inap warna ungu monokrom menjadi warna dominan, warna krem dan cokelat sebagai warna pendukung, dan warna hijau sebagai warna aksentuasi. Sebaliknya, pada area publik non medis seperti lobi, warna dominan adalah hijau sekaligus sebagai implementasi brand image perusahaan dimana logo Rumah Sakit Kartika Husada berwarna hijau, warna krem dan cokelat sebagai warna pendukung, sedangkan warna ungu sebagai warna aksentuasi.

\section{2) Konsep Dinding}

Menurut standar rumah sakit, dinding harus keras,rata,tidak berpori, tidak menyebabkan silau, tahan api, kedap air, tahan karat, tidak mempunyai sambungan, dan mudah dibersihkan. Secara keseluruhan konsep dinding berwarna putih dengan motif lengkung dinamis warna ungu lavender dikombinasikan dengan hijau pada area medis dan non medis menggunakan cat anti bakteri dan anti bau.Dinding pada area koridor-koridor lantai satu dibuat lengkung dinamis, dimana tampak atas menggambarkan transformasi bentukan lavender yang dipotong maupun dipetik. Dinding lengkung tersebut, bertujuan membentuk alur yang dinamis dengan sedikit liukan. Material dinding pada lantai satu berupa partisi dengan rangka hollow, bertujuan memudahkan perombakan dan konstruksi lebih ringan.

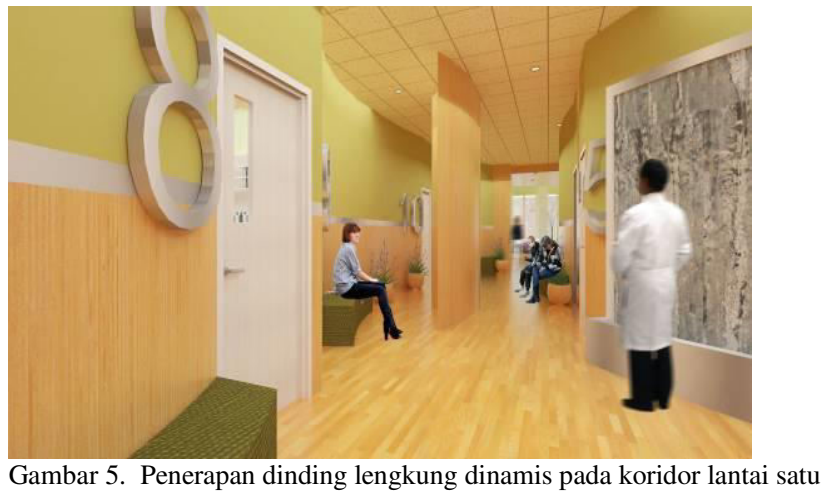

Sedangkan finishing dinding pada ruang poli-poli, serta kamar rawat inap VIP menggunakan kombinasi berupa custom wallpaper anti bakteria dengan vynil kayu anti bakteria.

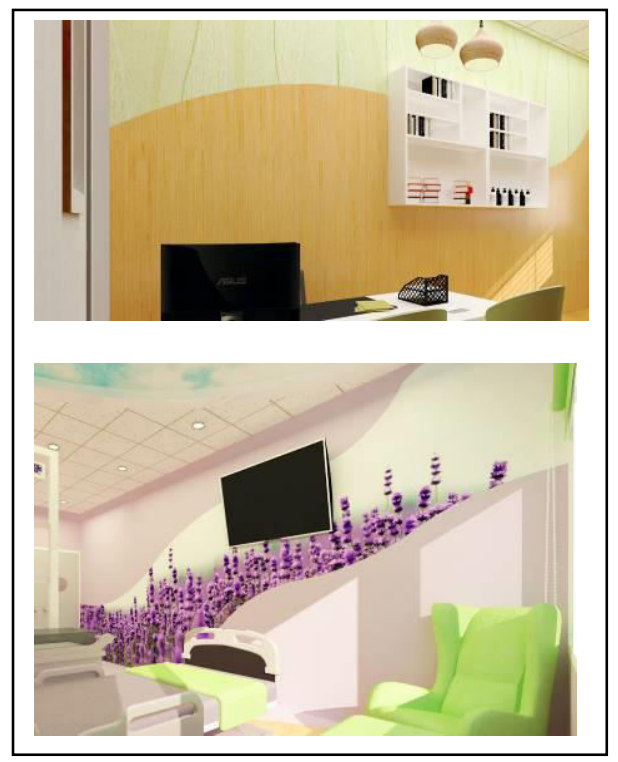

Gambar 6. Penerapan kombinasi dinding dengan wallpaper dan vynil anti bakteri

\section{3) Konsep Plafon}

Menurut standar rumah sakit, plafon yang digunakan harus kuat, berwarna terang, dan mudah dibersihkan serta menggunakan finishing cat anti bakteri dan bau. Secara keseluruhan konsep plafon pada rancangan ini cenderung bermain drop ceiling dan up ceiling bermaterial gypsum board dengan rangka hollow. Pada area yang membutuhkan task lighting diberikan drop ceiling tanpa rongga untuk mendekatkan lampu ke objek dan memberi kesan perbedaan area.

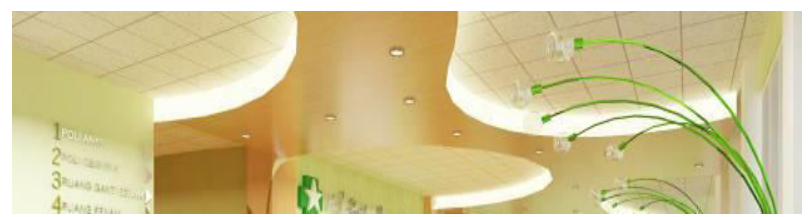

Gambar7. Penerapan drop ceiling pada lobi utama.

Pada area medis diterapkan visual grafis awan untuk menampilkan unsur kesejukan alam dan mendukung psikologi positif pasien. 


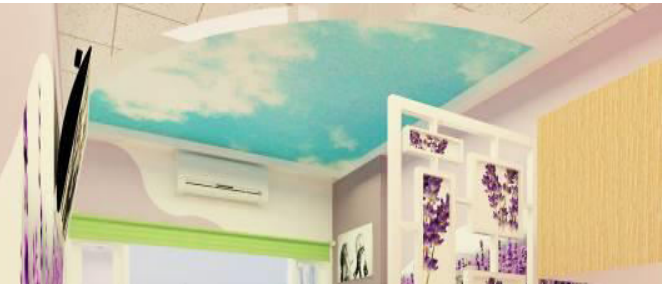

Gambar 8. Penerapan up ceiling cisual memotivasi pada kamar rawat inap VIP.

\section{4) Konsep Lantai}

Menurut standar rumah sakit, lantai dianjurkan menggunakan vynil anti bacteria atau epoxy serta penggunaan cove former untuk pertemuan dinding dan lantai pada area medis sehingga tidak memiliki rongga yang dapat berpotensi menjadi tempat berekembang biak bakteri. Selain itu penggunaan lantai karpet tidak dianjurkan khususnya pada area medis karena digunakan maneuver kursi roda maupun bed pasien serta menampun debu dan bakteri. Secara keseluruhan konsep lantai pada area medis dan non medis menggunakan material vynil anti bacteria motif kayu terang dengan permainan pola lantai lengkung yang harmonis dan dinamis.

Pada area lobi utama, koridor, serta poli-poli umum yang ada pada lantai satu, dominan menggunakan lantai vynil anti bakteria motif kayu untuk mengesankan menyatu dengan alam.

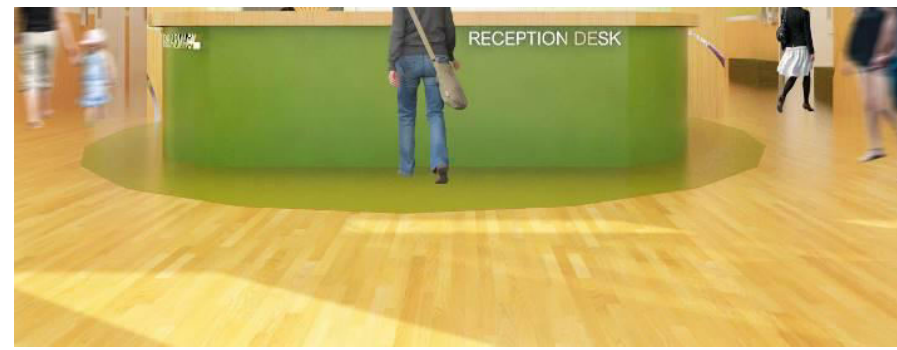

Gambar 9. Penerapan lantai vynil anti bakteria.

Pada area privat seperti kamar rawat inap VIP, pola lantai melengkung bertujuan memberi batasan privasi pada pasien dengan kombinasi vyinil anti bakteria kayu yang didominasi menggunakan vynil anti bakteria warna ungu muda

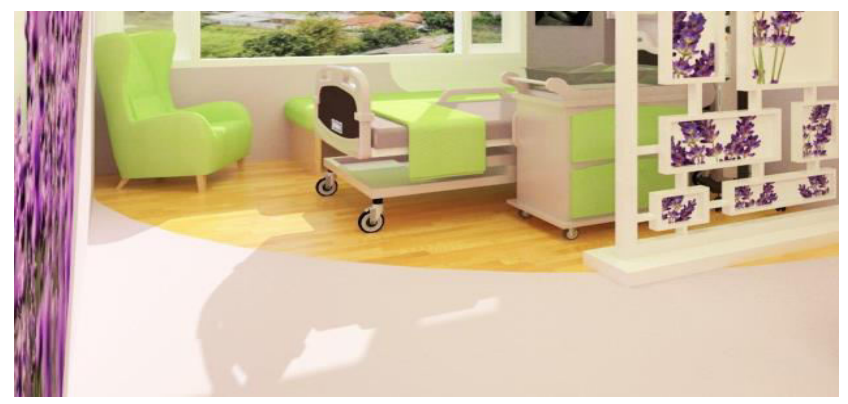

Gambar10. Penerapan pola lantai lengkung dinamis kamar rawat inap VIP

\section{5) Konsep Furniture}

Furniture banyak menerapkan desain yang sederhana namun nyaman dan empuk, agar ibu hamil utamanya serta pengguna lain merasa rileks dikombinasikan dengan warna healing. Pada beberapa area menggunakan bentukan yang tumpul dan tak bersudut guna meningkatkan keamanan serta menstimulus relaksasi.

Seperti pada area lobi utama, penggunaan furniture custom sofa lengkung dinamis sebagai furniture aksentuasi, dimana berkapasitas paling banyak yakni tiga orang, dengan warna ungu tua.

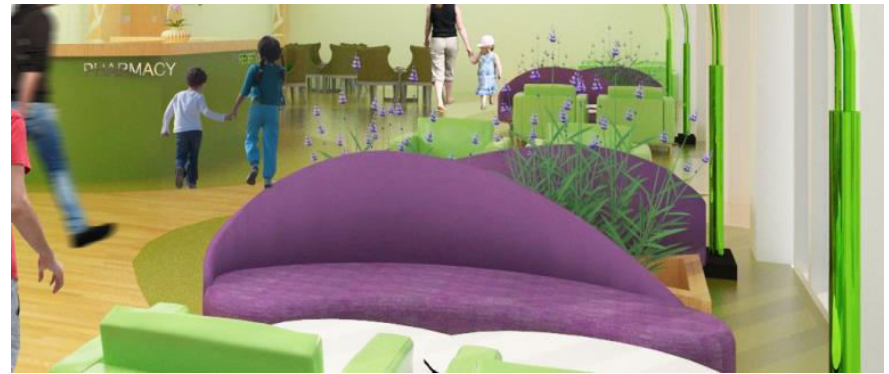

Gambar 11. Penerapan furnitur aksentuasi pada lobi utama

Sedangkan pada kursi ibu menyusui baik di ruang laktasi maupun pada kamar rawat inap VIP mengedepankan kenyamanan ibu dengan bentukan sederhana.

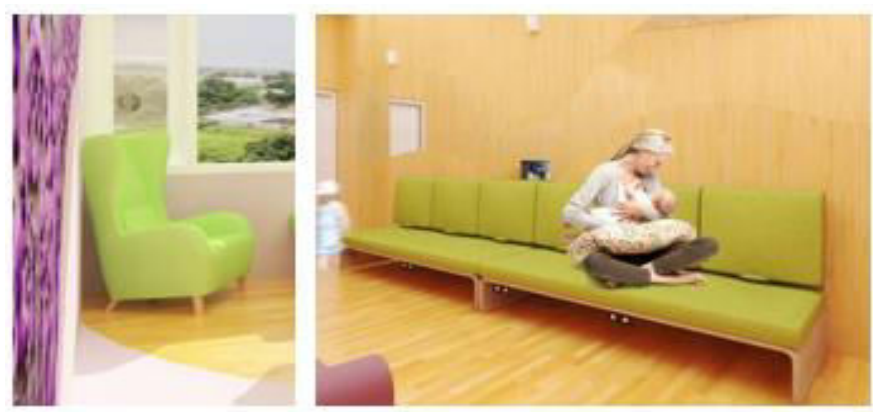

Gambar 12. Penerapan furnitur pada kamar rawat inap VIP dan ruang laktasi

\section{6) Konsep Aroma}

Sesuai dengan konsep utama yang diusung yakni healing environment dengan lavender sebagai lambang healing, maka dominansi aroma yang dihadirkan pada interior rumah sakit berupa aroma bunga lavender yang memiliki manfaat mengusir nyamuk, membantu penderita susah tidur(insomnia), serta membantu relaksasi bagi yang menghirupnya.

Pada ruang laktasi dan kamar rawat VIP utamanya, aroma lavender dihadirkan dengan aroma buatan dari parfum spray ruangan yang menempel pada dinding dan disemprotkan setiap menit-menit tertentu. Karena penerapan aroma alami tidak memungkinkan mengingat tingkat kehigienisan pada ruang privat ini lebih tinggi dari ruang publik. Disamping itu, cahaya matahari sebagai sumber energi utama tanaman lavender tidak dapat diperoleh secara maksimal.

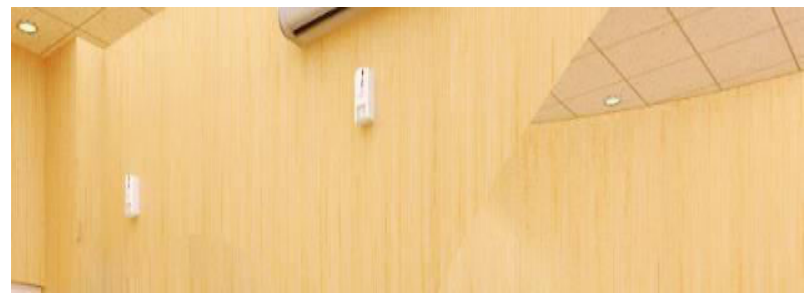

Gambar 13. Penerapan aroma lavender buatan 


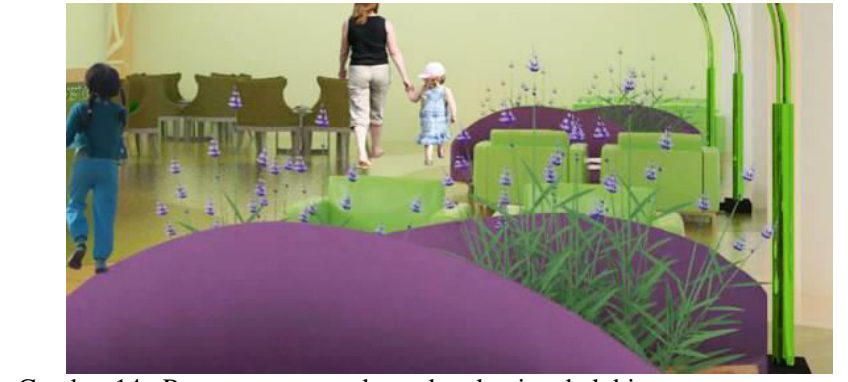

Gambar 14. Penerapan aroma lavender alami pada lobi utama.

Sedangkan pada area publik dengan dukungan sinar matahari melimpah yakni pada lobi utama, aroma lavender dihadrkan dengan tanaman bunga lavender yang berada pada indoor pot dan berfungsi pula sebagai elemen estetis.

\section{DESAIN AKHIR}

\section{A. Ruang Terpilih 1 : Kamar Rawat Inap VIP}

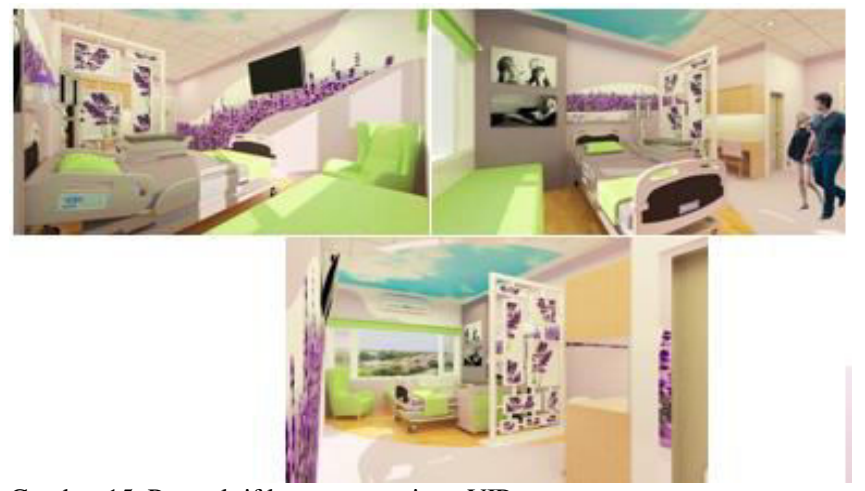

Gambar 15. Perspektif kamar rawat inap VIP.

Kamar rawat inap VIP di desain dengan kombinasi warna healing. Komposisi warna ungu sebagai warna dominan warna hijau sebagai aksentuasi, dan warna-warna kayu sebagai warna pendukung ditujukan untuk menstimulus ibu agar rileks dan tidak stress saat menghadapi masa pra dan pasca persalinan. Adanya elemen estetis berupa partisi corak lavender berfungsi sebagai sekat antara Kasur pasien dengan dapur sehingga privasi cukup terjaga. Desain up ceiling berupa nuansa awan-awan juga bertujuan menentramkan psikis pasien. Kemudian, pola lantai berupa vynil motif kayu dengan lengkung dinamis selain bertujuan sebagai area penanda privasi juga menambah nuansa healing. Selanjutnya, Dinding menggunakan material bata dengan finishing cat anti bakteri dan bau berwarna ungu muda dengan bentukan motif lengkung dinamis yang semakin naik dari aksen wallpaper pattern lavender bertujuan memotivasi psikologi pasien agar mood up tetap terjaga.

\section{B. Ruang Terpilih 2 : Lobi Utama}

Pada area lobi menggunakan dinding bata dengan finishing cat anti bakteri dan bau warna hijau muda, yang dikombinasikan dengan custom wallpaper motif spiral pada area resepsionis sebagai penanda aktivitas utama pada area tersebut. Kemudian, pola lantai dibuat lengkung dinamis menggunakan material vynil anti bakteri dengan pattern parket kayu terang dikombinasikan dengan lantai vynil polos berwarna hijau bertujuan sebagai wayfinding selaras dengan drop ceiling sehingga memudahkan alur pengguna, disamping itu memberikan kesan natural yang diimbangi oleh vertical garden di sisi kiri ruangan dan tanaman lavender dalam pot pada beberapa titik fasilitas custom curve sofa.

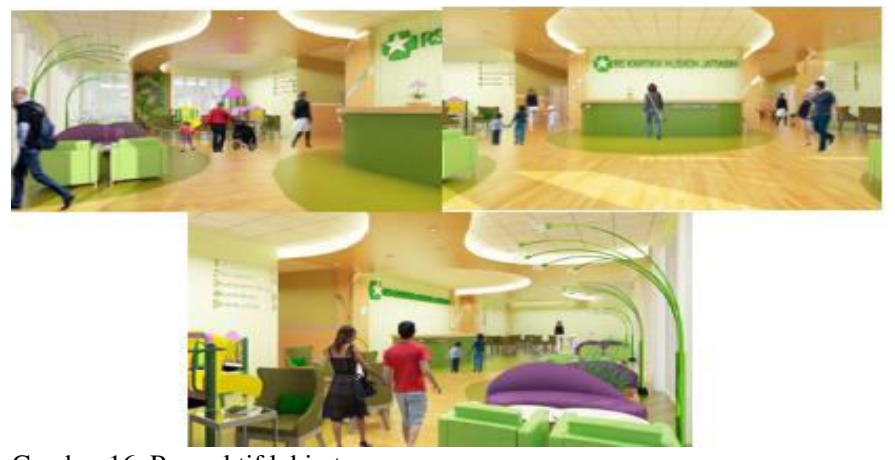

Gambar 16. Perspektif lobi utama

C. Ruang Terpilih 3 : ruang laktasi, poli bedah,poli gigi, dan koridor

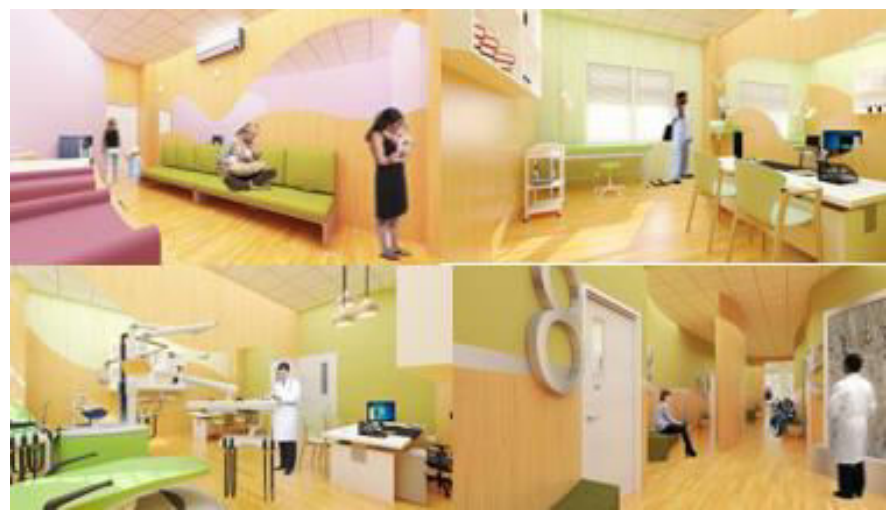

Gambar 17. Perspektif ruang laktasi, poli bedah, poli gigi, dan koridor

Pada ruang poli gigi dan poli bedah identitas rumah sakit sangat terasa dengan pemilihan warna dominansi hijau yang dikombinasikan dengan warna alam dari kayu. Penggunaan cermin dengan bentukan lengkung dinamis bertujuan agar ruangan lebih luas dan dinamis. Kemudian pada area koridor ruang tunggu pasien, juga menggunakan palet warna serupa dikarenakan termasuk area umum dengan pengguna terdiri dari dua gender, baik laki-laki maupun perempuan. Signage berupa angka yang cukup besar ditujukan memudahkan pengguna mencari poli yang dituju, yang berkaitan dengan signage awal di lobi utama.

Berbeda dengan ruang-ruang sebelumnya, ruang laktasi atau ruang ibu menyusui didesain dengan kombinasi warna hijau, warna alami kayu, serta warna warna ungu bertujuan sebagai penanda atau pembeda bahwa ruangan tersebut tergabung dalam instalasi kebidanan dan kandungan dimana pengguna adalah para perempuan.

\section{KESIMPULAN}

Pengelompokan dan layout ruang berdasarkan fungsi yang ada pada rumah sakit sangat penting bagi kelangsungan aktivitas para pengguna. Selain itu, pada hakikatnya desain interior mempengaruhi karakter penggunanya, seperti halnya pada rumah sakit dimana suasana interior yang tepat membangun psikologi positif bagi pasien, sehingga pasien 
merasakan ketenangan, kedamaian, dan ketentraman jiwa yang juga mempercepat proses penyembuhan tersebut. Pemilihan kombinasi yang tepat juga mempengaruhi perasaan pengguna, seperti halnya warna ungu yang memiliki arti damai dan spiritual, warna hijau yang memiliki arti kesejukan dan kesegaran, dan warna-warna kayu yang memiliki makan bersatu dengan alam dapat membentuk sikap pasien utamanya ibu pra dan pasca melahirkan menjadi rileks.

\section{DAFTAR PUSTAKA}

[1] Terri Zborowsky, R.N., Ph.D., and Mary Jo Kreitzer, Ph.D.,R.N, 2008. Jurnsl (Creating Optimal Healing Environments in a Health Care Setting)

[2] Conran, Terence. 2015. Conran on Colour. London : Conran Octopus Ltd.

[3] Philips, Charless. 2015. Transform Your Life With Colours. US : CICO Books 